\title{
Mega Events and Urban Conflicts in Valencia, Spain: Contesting the New Urban Modernity
}

\author{
Luis del Romero Renau ${ }^{1}$ and Catherine Trudelle ${ }^{2}$ \\ ${ }^{1}$ Department of Geography, University of Valencia, 46010 Valencia, Spain \\ ${ }^{2}$ Canada Research Chair in Socioterritorial Conflict and Local Governance, Department of Geography, \\ Université du Québec à Montréal, QC, Canada H3C $3 P 8$
}

Correspondence should be addressed to Luis del Romero Renau, lromerorenau@hotmail.com

Received 24 November 2010; Accepted 2 March 2011

Academic Editor: Bo-Sin Tang

Copyright (c) 2011 L. del Romero Renau and C. Trudelle. This is an open access article distributed under the Creative Commons Attribution License, which permits unrestricted use, distribution, and reproduction in any medium, provided the original work is properly cited.

The local and regional administrations of Valencia, Spain, have been working to position the city, which is the country's third largest in terms of population, as an international destination for luxury tourism through sports mega-events. Valencia's new image as a "mega-events city" has been criticized by citizens and urban-based movements on social and environmental grounds, resulting in various urban conflicts. The aim of this paper is to examine the causes and dynamics of these conflicts in order to understand the discourse and rationales behind the criticism. This will also include an examination of the ways in which these conflicts were managed by the local administration, especially in the months leading up to and during the events, when the city was receiving worldwide media coverage. Researching local print media, we focused on urban conflicts that took place in Valencia between 1995 and 2010. We also looked at the performance of urban-based movements and the administration as conflicting actors. One of the main findings was the strong consensual authoritarianism manifested by the administration and mega-event organizers when making decisions and managing urban conflicts related to mega-events.

"The period after the 1992 Olympic games left us a malignant virus: the 'business city,'
and quite often we have not resisted the occasion to sell it in pieces to the best bidder."

Jordi Borja, city planner

\section{Introduction}

Mega-events are critical instruments of economic development and modernization and serve as opportunities to reengineer a city's image. The ways in which mega-events boost urban economies have long been studied, especially in the case of the Olympic Games and World Expos [1-5]. However, the event landscape today has grown to include a much wider range of mega-events that impact cities, from sports events other than the Olympic Games [6] to international festivals [7] and religious gatherings [1].

In the case of Valencia (Figure 1), the third largest city in Spain, population-wise, local and regional administrations are seeking ways to strengthen the city's position in the international arena by staging different sports mega-events (e.g., Formula 1 races, regattas, tennis tournaments, Moto GPs) that will allow the city to establish itself as an international destination for luxury tourism. The events take place in former industrial sites that are close to the port and next to working-class neighborhoods such as Cabanyal-Canyamelar or Nazaret, both located in the city waterfront district of Poblats Marítims.

The organization of mega-events generally occurs under time pressure, providing an expedient context for promoters and the administration to implement actions that would generally be met with more resistance. This has given rise 


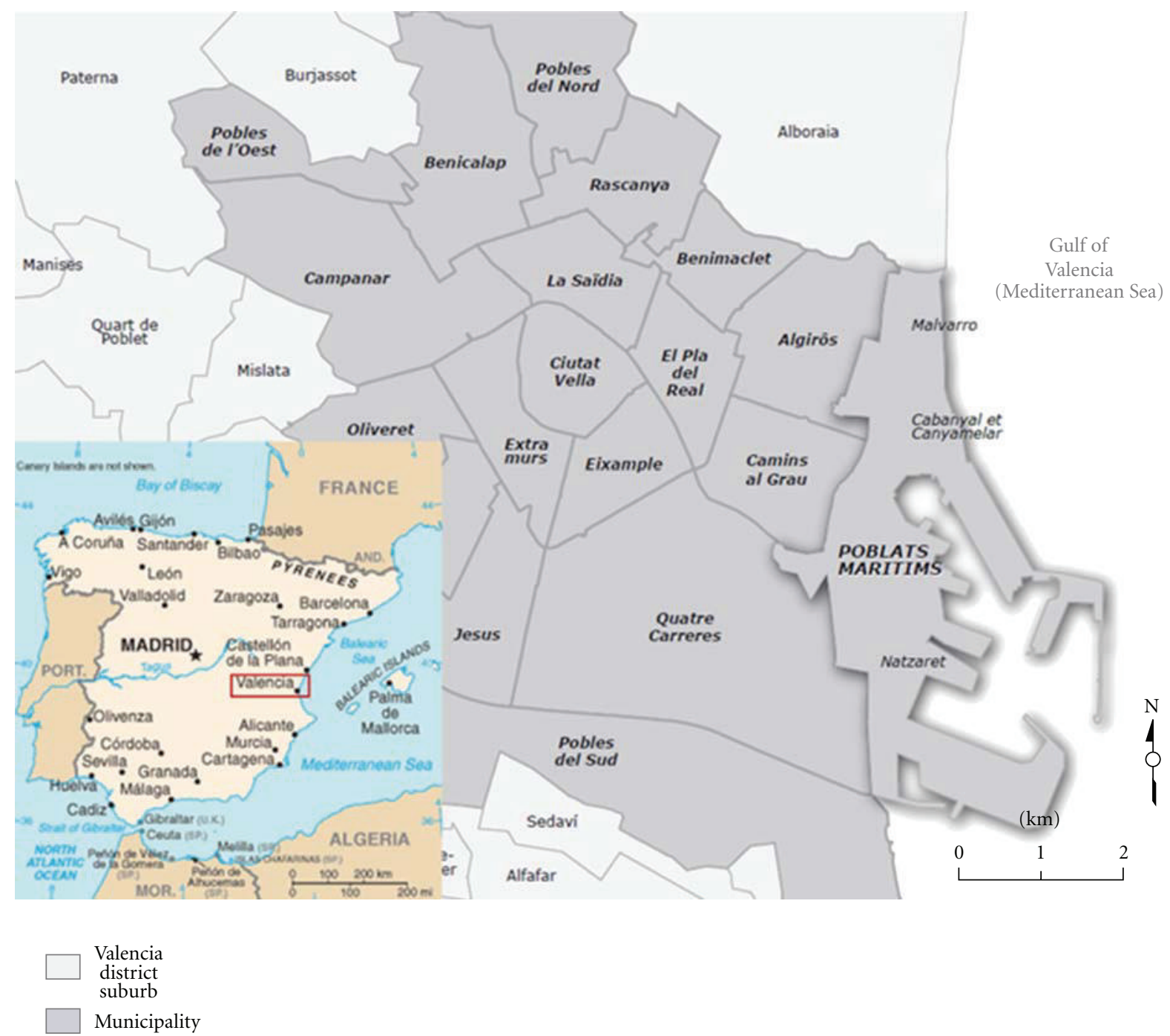

Figure 1: Valencia and its districts. Source: City of Valencia, 2009.

to a "state of exception" mentality among decision-makers of Valencia. In the case of the America's Cup, the authorities had only four years to prepare the port of Valencia for this important sports event, from the nomination of the city in 2003 to the first regattas held in 2007. The city faced even more pressure in January 2007, when a deal was closed to host the Formula 1 European Grand Prix for seven years in a row. For this, an urban race circuit had to be built within a record period of one year [8].

Despite the boosterist and optimistic discourse that dominates local media and politicians, many citizens from the suburbs surrounding the port have developed a dislike for these mega-events. This had led to numerous urban conflicts in the port area between citizens and urbanbased movements on the one hand, and local authorities and promoters on the other hand. Noise, environmental problems, the privatization of public spaces during the events, increases in rents and housing, and evictions were some of the complaints expressed by citizens involved in protests. They strongly criticized these sports mega-events for having completely changed the urban landscape and social composition of certain areas of the city within a short period of time.

The focus of this study is on the dynamics of these urban conflicts and how these demonstrate that sports megaevents have significant negative impacts for many citizens. In particular, it examines how urban actors react to those conflicts, and how those reactions shape the postevent context in the city.

The paper argues that this new mega-events trend in Valencia constitutes, beyond the attempt to create a "fashion city" to attract tourism and investments, a tool used by the established leaders of Valencia society to consolidate their power over the masses. We show how these sports megaevents were used as a catalyst for the initiation, expansion, and intensification of the reurbanization process of the bluecollar neighborhoods in the Poblats Marítims district and how this reurbanization has led to gentrification processes in one of the most valuable areas of the city: the Valencia waterfront. Finally, we discuss how the conflicts resulting 
from these reurbanization and gentrification processes were managed with an authoritarianism that exploited the "state of exception" mentality to serve its own interests.

\section{Mega-Events and Urban Conflicts}

Mega-events or "hallmark events" are large-scale tourist events of a limited duration, designed to generate attention and attract support (often in terms of public funding and private investments) in order to stimulate redevelopment, increase tourism, boost economic investment, and create an image for the city [6]. In an effort to improve their competitive position in the current industrial and economic crisis caused by globalization, cities seek to strengthen and promote new sectors to attract international investments, from universities, sports competitions, and museums, to theme parks and technology parks $[9,10]$. The hosting of all types of mega-events, such as sports mega-events, expos, and international summits, help to build a positive image and to insert a city into new networks [10]. The nominated cities selected to actually host an international event benefit from media attention for the duration of the event, if not longer. This media attention, including national and international coverage, as well as television, print, and electronic media, also functions to build a consensus between the different urban actors in the sense that it develops a sense of identity and belonging among the actors ("Wir Gefühl" or "collective sense").

Spanish cities serve as good examples for illustrating issues surrounding mega-events, which have attracted a renewed wave of interest in the 1990s. The 1992 Barcelona Olympic Games and the 1992 Seville and 2008 Zaragoza expos are some cases of mega-events that were accompanied by substantial urban renewal plans. For this, municipal administrations implemented urban renovation plans in old industrial areas or slums to strengthen the city's image abroad, including its "position" or "ranking" according to magazines, international institutions, and agencies that measure cities' attractiveness for international capital. The success of the 1992 Olympic Games in Barcelona, in terms of visitors and the city's image in media worldwide, then motivated other cities throughout the world to bid to host the Olympic Games, among them Madrid, which has bid twice for the Olympic Games.

The eagerness to host mega-events is seen by some authors as a new feature of capitalist urbanization [11] in that it comprises a strategy of cities in the postindustrial era to continue with capital accumulation through the commodification of leisure activities [7]. Holding mega-events offers an excellent opportunity to induce profound urban change within a given area, to insert into the market new areas for urban (re)development, and to increase land value, especially when the mega-event leads to the construction of new landmarks such as stadiums, cultural centers, or other key infrastructures. Moreover, apart from their impacts on the urban structure, the organization of mega-events serves as a strategy to pacify citizens in that it imbues them with a consumerist ideology [12]. Similarly, Harvey [13] notes that large celebrations, festivals, and mega-events are important not only for generating profit and supporting local investments, but also for pacifying local people-a form of ideological control referred to as "bread and circuses."

Nevertheless, mega-events have been met with increasing opposition from citizens in cities around the world, escalating into a multitude of urban conflicts. The last decades have seen an overall increase in the number of urban spatial conflicts, many of which were related to mega-events. The reasons for this rise in conflict activity are seen in the increase of challenges facing urban neighborhoods (e.g., environmental protection, heritage, security, quality of life, and identity preservation) and a significant loss of confidence in the established forms of local power, especially political parties and leaders [14-17]. In the case of sports mega-events, especially the Olympic Games, opposition from citizens, urban-based movements, and antiglobalization movements is now commonplace.

For example, residents from Denver, Colorado, expressed their opposition to the 1976 Winter Olympics as early as 1972. While the city had won the bid to host the games, concerns mounted among Coloradans about the enormous cost as well as the environmental damage that would result from the mega-event. Following public consultations, $60 \%$ of voters then rejected the idea of holding the Olympic Games in their state [18]. In its report on housing rights relating to sports mega-events, the Centre on Housing Rights and Evictions, an international NGO based in Switzerland, denounced the massive evictions that occurred right before the 1988 Seoul Olympics and the 2008 Beijing Olympics, the increased discrimination and marginalization against Romani gypsies during the 2004 Athens Olympics, and the reinforcement of gentrification processes during the 1992 Barcelona and 1996 Atlanta Olympics [6]. In the 2010 Winter Olympic Games in Vancouver, hundreds of citizens and more than 50 community-based organizations contested the holding of the games because of the skyrocketing costs of the event, the undeniable gentrification of Vancouver's Downtown Eastside, the expansion of sports facilities on First Nations territories, and the environmental impacts of the Games in Whistler, a natural environment that had been well preserved before the games [19].

Other sports mega-events, such as the 1987 America's Cup in Fremantle, Australia - and an event also held in Valencia and discussed in this paper-have been criticized for their strong impacts on the housing market. Cox [20] notes that in the case of Fremantle, the sports event led to a significant loss of low-income housing, significantly affecting tenants of boarding houses.

These examples show that sports mega-events are catalysts for conflict activity in many cities. Unfortunately, the case of Valencia is not an exception. The study area is the seashore district of Valencia (Figure 1). This area has changed significantly in recent years due to the collapse of fisheries and industrial activities and the appearance of new economic activities based on luxury leisure and tourism. The data on the urban conflicts were collected through content analysis of print media. From an operational standpoint, we define an urban conflict as an event involving actors 
who confront each other about an urban project, usually a (re)development project but also a project related to the access and management of urban resources [21-23]. Local or national print media, (we included only newspapers that publish factual, verifiable information in a nonsensationalist manner. Thus, we did not consider sensationalist tabloids or magazines focussing on stars and celebrities) despite their biases [24], are valuable data sources for the study of urban conflicts and social protests [25-27]. This is especially true for mega-events, as these represent a major interest for local media of the host city.

\section{Poblats Marítims: A Tale of the Valencia Seashore}

\begin{abstract}
"Beyond lie the harbor, prickly with masts from the shipping, and flags everywhere, a maze of cross-trees and yards, red and black smokestacks and cranes that looked like gibbets [...] the tall buildings of the Grao, warehouses, office buildings, - the aristocracy and money of the port, and then a long straight line of roofs, the Cabanyal-Canyamelar, and the Cap de França, a rambling agglomeration of many colored houses."
\end{abstract}

Vicente Blasco Ibánez (1895) [28].

This is what Poblats Marítims looked like according to the Valencian writer Blasco Ibánez [28], one century ago. The formation of Poblats Marítims (Maritime villages) dates back to the 13th century, when a group of fishermen settled there. At the same time, with the expansion of European trade, the city of Valencia was starting to flourish thanks to its opening to the Mediterranean (Figure 2). These fishermen, as well as sailors, were the ones who built the barraques, the traditional Valencian houses found mainly in rural areas.

For many years, the villages of El Cabanyal, Canyamelar, and Cap de França formed an independent municipality known as Poble Nou de la Mar (New Village of the Sea) while the village surrounding the port was another municipality called Vilanova del Grau (New Village of the Harbor). Both were merged into Valencia in 1897 to form the Poblats Marítims district. Fishing and shipping were the predominant economic activities in both municipalities. Nevertheless, at that time, there was a distance of almost three kilometers between the city limits of Valencia and the coast.

In 1957, Valencia suffered the worst floods in the city's history, impacting in particular Poblats Marítims. This led to the construction of a new artificial riverbed along the southern part of the city to carry water in case of potential floods. However, this huge infrastructure affected the southern villages of Poblats Marítims, especially Pinedo and Nazaret, in that the new riverbed isolated them from the rest of the city of Valencia.

In the following decades, the city of Valencia expanded toward the seashore along the old roads linking the city to the port. The road infrastructures were developed at various periods to adapt to an ever increasing volume of traffic and
Table 1: Socioeconomic data: Poblats Marítims district and Valencia.

\begin{tabular}{lcc}
\hline & $\begin{array}{c}\text { Poblats } \\
\text { Marítims }\end{array}$ & Valencia \\
\hline \% Illiteracy rate & $3.07 \%$ & $1.82 \%$ \\
\% Population with less than a & $13.22 \%$ & $9.31 \%$ \\
grade 9 education & $9.14 \%$ & $7.81 \%$ \\
\% Unemployment rate & $44.23 \%$ & $47.29 \%$ \\
\% Economic activity rate & 74.59 & 77.35 \\
Life expectancy (men) & 82.71 & 83.79 \\
Life expectancy (women) & & \\
\hline
\end{tabular}

Source: INE (2001).

thriving shipyard activity. However, the majority of the former villages of Cabanyal-Canyamelar remained traditional fishing communities rather than becoming suburbs of a bigger city, even after Valencia had expanded to the point of incorporating the Poblats Marítims district.

The crisis of the fishing and shipping industries in the 1970s then initiated the slow decline of Poblats Marítims. In the early 1980s, unemployment, social problems, and pollution (from more than a century of shipping and industrial activities, as well as the city dumping sewage into the harbor) had degraded the district. In spite of the waves of immigration that flowed into Valencia in the 1960s, the population of Poblats Maritims began to drop during this period-namely, from 63,528 people in 1970 to 58,643 in 1991, representing an $8 \%$ population loss (Ayuntamiento de Valencia, 1991). The industrial crisis affected especially the older suburbs, such as Cabanyal-Canyamelar, which experienced a $33 \%$ drop in the population during this same period. By the end of the 1990s, Poblats Maritims had the worst socioeconomic status within the city (Table 1 ).

At the end of the 20th century, a wide range of urban renewal projects for the old port and the historic suburbs of Cabanyal-Canyamelar were presented by the local administration. A new overall urban plan for the area, in discussion since 1988, was officially launched by the City Council of Valencia in 1998 with the announcement of the enlargement of Blasco Ibáñez Avenue as its main project. This part of the plan, involving the destruction of more than 1,600 dwellings, has been strongly contested by urbanbased movements to this date (see [29]). Another project called Balcón al Mar was an attempt to transform the former industrial port of Valencia into a broad leisure and business area with luxury boutiques and cinemas, similar to the Port Vell project in Barcelona. However, Balcón al Mar never saw the light of day due to a lack of economic support [30].

Because both of these projects failed, the local government sought new tools to promote urban redevelopment and to restructure the area. For this, sports mega-events rapidly emerged as a tool of choice. In 2003, Valencia was nominated to host the 32nd America's Cup, to be held in the harbor area. This marked the beginning of an important wave of urban renovation and redevelopment based on sports mega-events. However, residents were far from content with this strategy, leaving the local council to cope with a new form of urban 


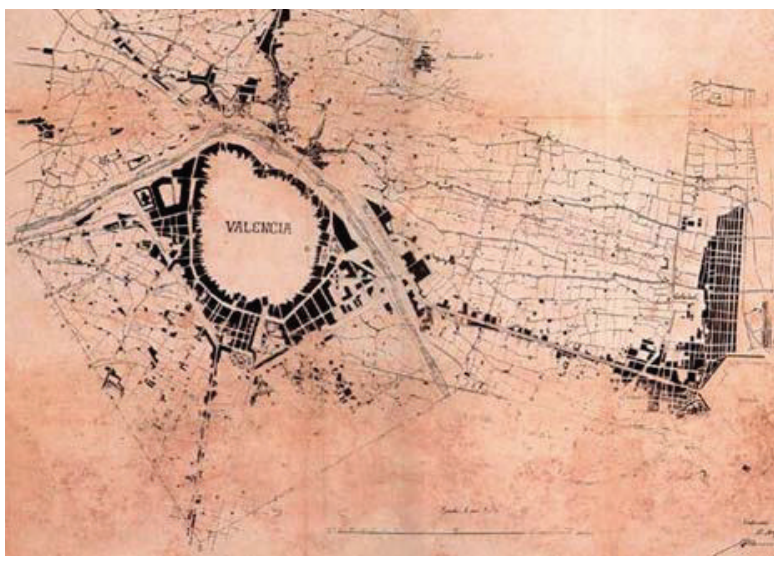

(a)

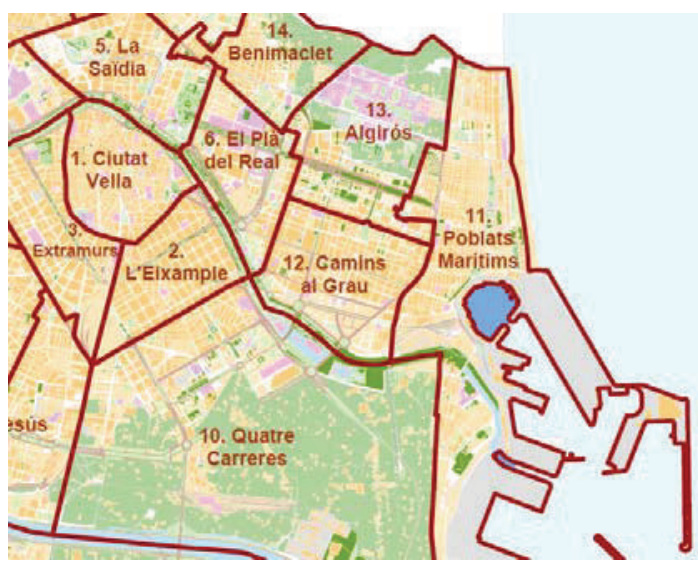

(b)

FIGURE 2: Valencia in 1900 and today showing district divisions as well as one century of growth toward the seashore. Source: RIVA Plan, Valencia city council (2006).

conflict. This type of conflict activity qualifies as new because the antagonism revolves heavily around the predetermined start date of the mega-event. In other words, as these events cannot be postponed, the parties for or against the event put all their energy into either realizing or preventing the staging of the event by that determined date.

\section{Urban Conflicts and Mega-Events}

In this paper, we understand an urban conflict as an event evolving in the public sphere and involving at least two actors (individuals, collective, and/or institutional) competing around issues related to urban land-use, urban infrastructures and services, and more broadly, around the conditions of urban life $[31,32]$. In this case, the main actors in conflict are the local and regional administrations of Valencia, which have jurisdiction over urban and spatial planning issues, and the citizens, who came together in adhoc "plataformas" or in neighborhood associations to contest the urban renewal project. These citizens are supported by wellestablished urban-based social movement organizations.

The conflict analysis method, used to study urban conflicts linked to sports mega-events in the Valencia waterfront district of Poblats Marítims, was initially proposed by Janelle and Millward [33], Janelle [34], and Ley and Mercer [35] and later developed by Trudelle [24]. The data on urban conflicts were collected through the content analysis of regional print media. All the issues of the daily newspaper El Levante published between 1995 and 2010 were examined: 411 articles concerning urban conflicts were published, describing a total of 25 conflicts that took place in the district during this period. These urban conflicts are varied and range from a protest against the revitalization of a former industrial site, to the sustained demand to close a polluting and noisy industry next to the port, or to squat actions in an abandoned building in El Cabañal. Only three conflicts were directly related to sports mega-events. One concerned the construction of an urban street circuit, another one the potential impacts of the America's Cup in Valencia, and the third one the enlargement project of the Valencia marina. However, 78 out of 411 articles (19\%) focused on these three conflicts. The high proportion of articles recounting conflicts related to mega-events shows their relative importance. Figure 3 locates the conflicts found in the Poblats Marítims area during the study period (19952010). Apart from the conflicts located in the district, the database also contains information related to conflicts that took place in the surrounding suburbs. Spatially, each conflict is represented by its "space of intervention" [32], which is the specific space where the contested project, or urban change, is to be implemented or where its anticipated negative impacts are expected to unfold. For instance, in the case of the conflict over increasing truck traffic in the port, causing noise and pollution problems, the space of intervention is the street and the surroundings where the noise and pollution problems manifest. In the case of the Formula 1 project, the space of intervention is the whole area of land that had been transformed by the construction of the street circuit and which is also where the America's Cup conflict took place.

The various shadings of the map indicate the respective unemployment rates of those district sections in 2001. The district of Poblats Marítims as a whole had higher unemployment rates than the surrounding districts, which is consistent with the data presented in Table 1. In a comparative research of urban conflicts that occurred in Valencia and Montreal, we shed light on a significant statistical relationship between urban poverty and conflict distribution, showing that clusters of poor suburbs with intense and long-drawn conflicts exist in both cities [36].

Nonetheless, in the following paragraphs, we focus on the three conflicts related to sports mega-events, examining how these conflicts began and why the mega-events can be interpreted as a catalyst of urban gentrification and as a tool by the leading minority to consolidate their power over an urban area that has an enormous economic potential given that it is the waterfront of a Mediterranean tourist city. 


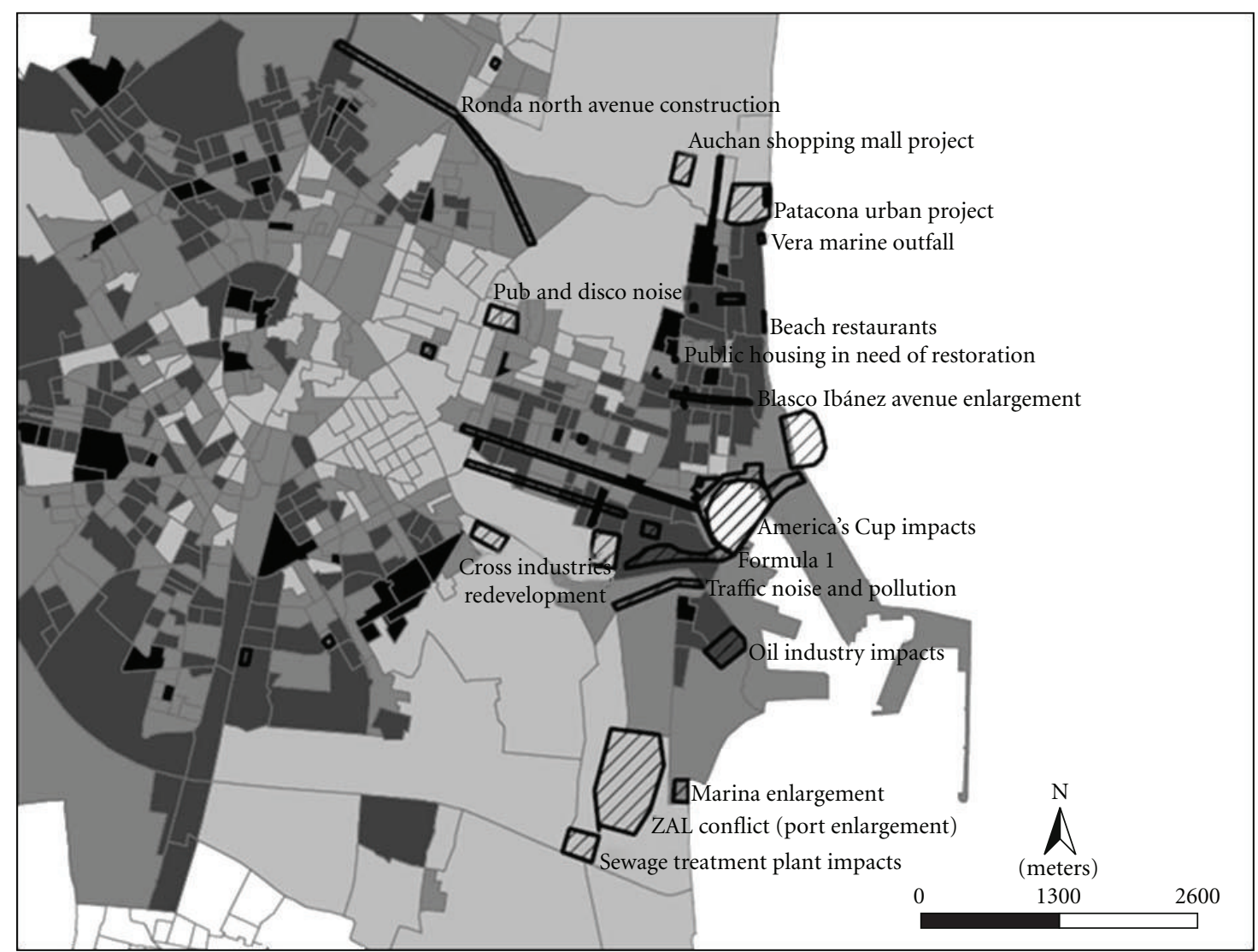

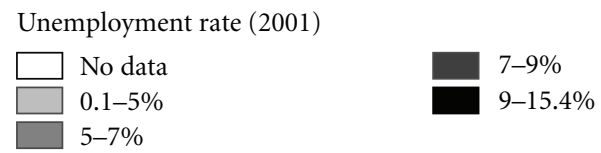

Figure 3: Urban conflicts and unemployment rate in Poblats Marítims and surrounding districts. Sources: INE census data and database on urban conflicts of Poblats Marítims and its surroundings.

4.1. Valencia's First Sports Mega-Event: The 32nd America's Cup (2007). The aim was to change the image of Valencia, thereby converting the city into a major tourist destination like Barcelona. Prior works and historical restoration projects undertaken by Valencia had not proven sufficient to set the city apart as a great destination for tourism, much less luxury tourism. Something was still missing that could attract international public attention to Valencia at a more symbolic level. The idea to host a sailing competition to be attended by an elitist public, the America's Cup, was then embraced by the local administration and developers. At the end of 2003, Valencia was designated to organize this competition that, despite being heralded as "the oldest sports trophy in the world," was unknown to a large part of the public.

The hosting of the America's Cup in Valencia is based on the same mechanism as the Olympic Games and international expositions. That is to say, the mega-event is internationally publicized as serving to redevelop poor urban neighborhoods. The 32nd America's Cup took place in the former industrial port of Valencia and had the objective of "constituting a catalyst for the implementation of key urban projects for the future of Valencia" [37]. Therefore, immediately after the nomination of the city, the old port of Valencia, until then an open leisure area, was closed to "adapt" the urban structure to holding the sailing competition. Consequently, two marinas for megayachts were constructed and the former docks, which had remarkable heritage buildings, among them tinglados (port warehouses) from the beginning of the 20th century, were closed and replaced by the bases of the regatta teams. Trendy cafés and restaurants and Louis Vuitton boutiques were opened, and a brand new pavilion designed by star architect David Chipperfield was constructed for 35 million euros to accommodate the press and visitors during the competition, along with the five-star luxury spa hotel Las Arenas, which was built next to the old fishing houses of El Cabanyal (Figure 4). This comprised the beginning of a new gentrification process in the core of a former working-class suburb.

One of the most polemic aspects of this huge project is that it received major support from public funds even 


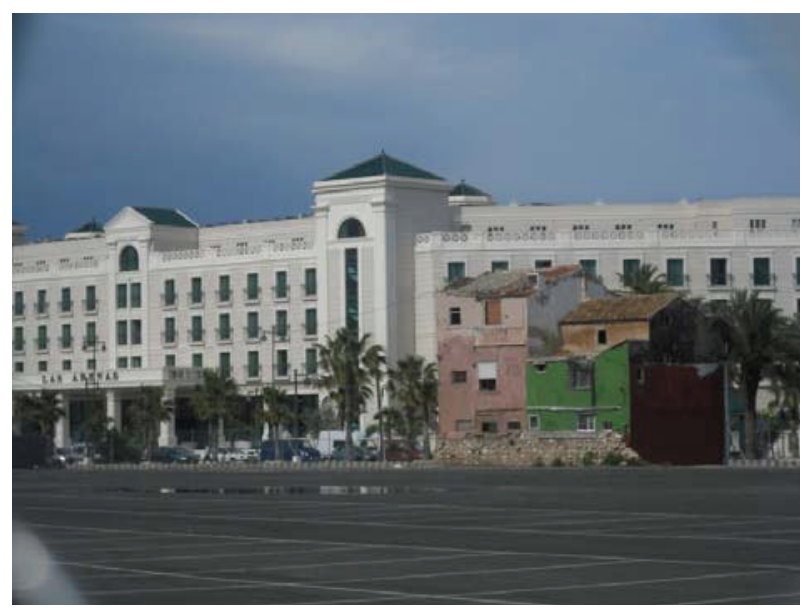

FIGURE 4: Gentrification takes place through physical destruction of a working-class suburb. The Las Arenas five-star spa hotel was built next to fishermen dwellings, from which tenants were evicted and which were then demolished. Photograph: S. Mayordomo (2008).

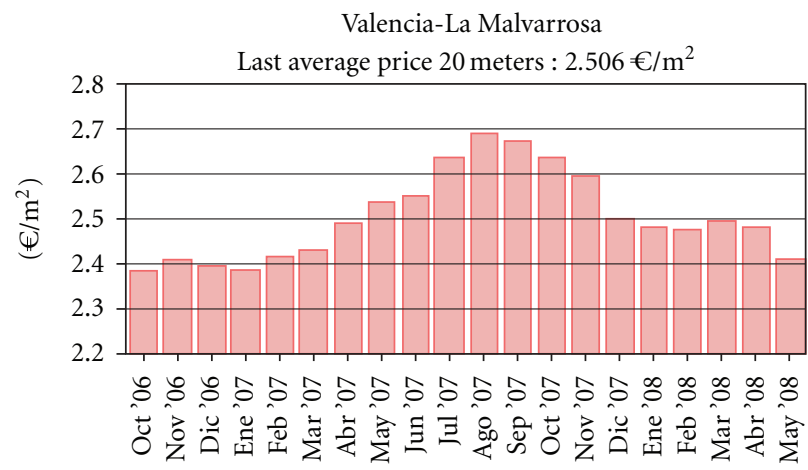

(months)

Figure 5: Housing prices in the La Malvarrosa suburb, 2006-2008. Source: http://www.fotocasa.es/ (2011).

though it served exclusively elitist purposes. For example, the urban renewal project, costing more than 140 million euros, created a hub for nautical tourism [38]. However, these huge investments have had very little positive impact on the immediate neighborhoods of Cabanyal and Malvarrosa. In fact, the most striking effect of these investments was the significant rise of housing prices in the areas surrounding the port, especially the old port and the Malvarrosa suburb. Figure 5 shows the average difference in housing prices per square meter before and after the America's Cup in the Malvarrosa suburb. The price increase was maintained for almost a year after the event and only stopped with the onset of the international economic crisis.

The cost of housing rose by an average of 300 euros per square meter, making access to housing more difficult, if not impossible, for low-income families [39]. Even several months after the America's Cup, the price was still over 100 euros (per square meter) more expensive than before the mega-event. Under these circumstances, the increase in the housing supply, namely, 2131 new housing units

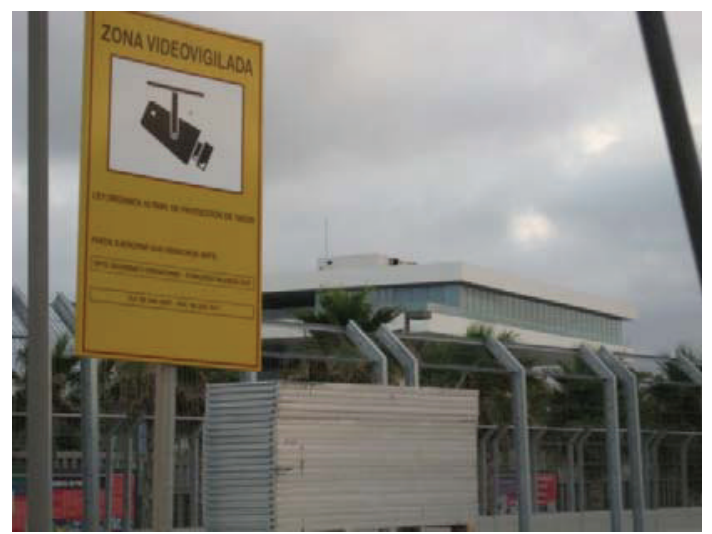

Figure 6: America's Cup enclosure. The area was monitored and enclosed with a double fence. These security systems remained long after the America's Cup ended. Photographs: Luis Del Romero (2008).

constructed in Poblats Marítims between 2001 and 2007, did not contribute to improving housing conditions for the poor.

In all, this comprises the beginning phases of gentrification as well as a good example of the rent gap theory [40]. The rent gap suggests that gentrification is one way to increase capitalized ground rent on suburbs that have been devalorized by obsolete land uses. In this case, public investments increased immediately capitalized ground rent in the parcels surrounding the America's Cup. However, as this rent increase occurred throughout the entire suburb, the gap with the potential ground rent that increases with time was reduced. Subsequently, the average prices of dwellings rose and the suburb as a whole began a gentrification process.

Another source of polemic and protest concerned the extensive safety and security measures undertaken to protect the exclusive tourists who came to the event in their yachts. The entire port area was fenced off and video cameras were installed to monitor any suspicious movement (Figure 6). The access to the port was controlled by security guards who made use of metal detectors. What was once a public space thus became a private and monitored space.

Protests against the holding of the America's Cup came especially from environmental and citizens' groups linked to left-wing movements. They claimed that such events do not cope with the real problems of the district, such as unemployment or poverty, and that the public investments in the America's Cup was taken from the budget for facilities and services that are needed in the district and the city as a whole [41]. Another major irritant was the lack of public participation in the organization of the event. The America's Cup Management (ACM), a private consortium collaborating with the national and local administrations, designed the renewal project and managed the organization in a way that excluded the possibility of participation of local urban-based movements. No social, cultural, or ecological local associations in Poblats Marítims were given the chance to participate in the decision-making process in any way, and their demands were completely ignored by the ACM forum. No public participation forums were set 


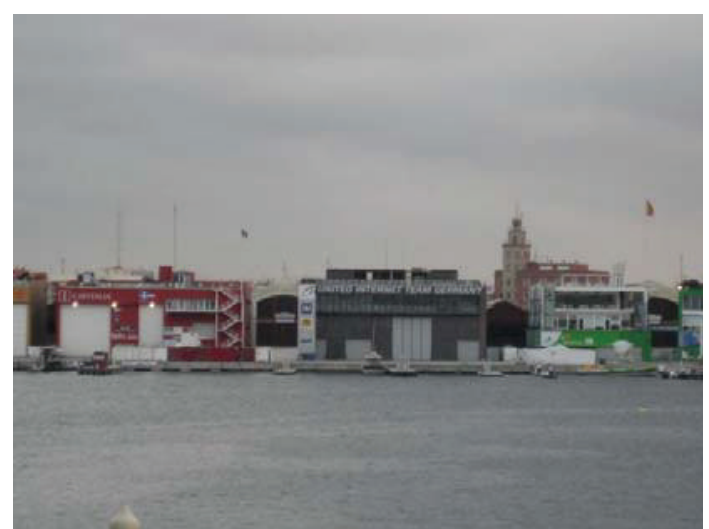

FIGURE 7: Sailing teams headquarters in the old port of Valencia.

up, even though the America's Cup project brought about a substantial transformation of the port, affecting the whole neighborhood and especially the city waterfront (Figure 7 ). Therefore, the role of citizens was reduced to a passive audience in this key urban renewal plan.

Finally, Valencia held two editions of the America's Cup, one in 2007 and one in 2010. The second edition had, according to the official America's Cup consortium, a total number of 200,000 visitors, which is a modest amount compared to the number of tourists - more than two million-who came during the same year to the local Fallas festival.

The main challenge for the city of Valencia today is how to best make use of the port, restructured specifically to host the America's Cup, in times when there is no megaevent. The public administration intends to attract future mega-events to be held in the port, thereby consolidating this area as a theme park for sports competitions. A step in this direction has already been made with the construction of a street circuit for Formula 1 competitions (Montecarlo is the only other city with a street circuit). However, this urban project led to citizens' protests about noise and air pollution.

\subsection{The Consolidation of the Sports Mega-Events Strategy: The} Formula 1 Street Circuit. The street circuit was a significant component of the urban renewal strategy based on sports mega-events (Figure 8). The America's Cup had attracted the first international and national promoters to the area, and these massively invested in urban renovation in the port and its surroundings. The first wave of gentrification then hit the Poblat Marítims port area, with five-star hotels, Louis Vuitton boutiques, and new restaurants appearing next to the old docks, accompanied by hikes in housing prices and the construction of new condos (Figures 9 and 10). However, the rest of the district still needed considerable work in order to attract promoters and investors. In comparison to other cities, where promoters or individuals are the protagonists of urban renovation processes [42], in Valencia, the local and regional administrations were in charge of the renewal process from the beginning.

The plan to create an urban street circuit was unveiled in early February 2007. Formula 1 manager Bernie Ecclestone, who had visited the city for the America's Cup, encouraged the city of Valencia to become one of the select cities entitled to hold Formula 1 Grand Prix races. Immediately, both the local and regional administrations jumped in and offered to build the entire necessary infrastructure with a budget coming from public funds, at the initial cost of 60 million euros [43]. The street circuit was designed on abandoned industrial sites in the port, at the Turia river mouth, and very close to the suburbs Grao and Nazaret. At the time, Nazaret had already been under redevelopment for the America's Cup mega-event, but Grao was still a poor suburb in the outskirts of the city. The possibility of having a Formula 1 street circuit so close to this area then attracted urban promoters, who invested massively in luxury housing.

The Formula 1 project provoked a stronger reaction from civil society and urban-based organizations than did the America's Cup. Moreover, the main opposition parties claimed that a street circuit would be an expensive and harmful infrastructure for a city [43]. Nine citizens' organizations of the district as well as various environmental and cultural associations created a movement called Fórmula Verda (Green Formula) to contest the holding of such an event in Valencia. The main grounds for complaint were the total absence of a public participation mechanism in the implementation of the Formula 1 plan, the severe environmental impacts that the street circuit would have on the city, and the problems of isolation and noise that the Nazaret suburb would suffer during the races. Far more than a NIMBY reaction against an undesirable infrastructure, this well-organized protest offered alternatives and ideas for the development of the Valencia waterfront to promote a better environmental performance and greater public participation. However, the many demonstrations, public meetings, debates, and published articles generated by this network of organizations were hardly covered by the international or national press. Instead, the media preferred to highlight the importance of having such an important sports event in Valencia.

For the local and regional administrations of Valencia, the completion of this infrastructure by the deadline was a major imperative, so much that they implemented a substantial reform of the existing Valencia Urban Plan and the Strategic Plan. The arguments used to defend this megaevent pertained to the huge economic spin-offs purported to ensue, the improvement of the city's image, and the long overdue urban renewal of the port area. The criticism and demands made by the Formula Verda movement were completely ignored by the local administration, led by the conservative Partido Popular. The latter argued that the majority of the population must be in support of the project because the party itself had won the local elections that very same year [44]. As in the case of the America's Cup, there was no public participation at all, no public debate with all the key actors, and no public consultation. The restructuring of the waterfront was "sold" as a construction project that would bring in new perspectives on a continual basis [44] and not as a sports facility. With an absolute majority of the conservative Partido Popular in both the local council and the regional government, the decision to transform the 


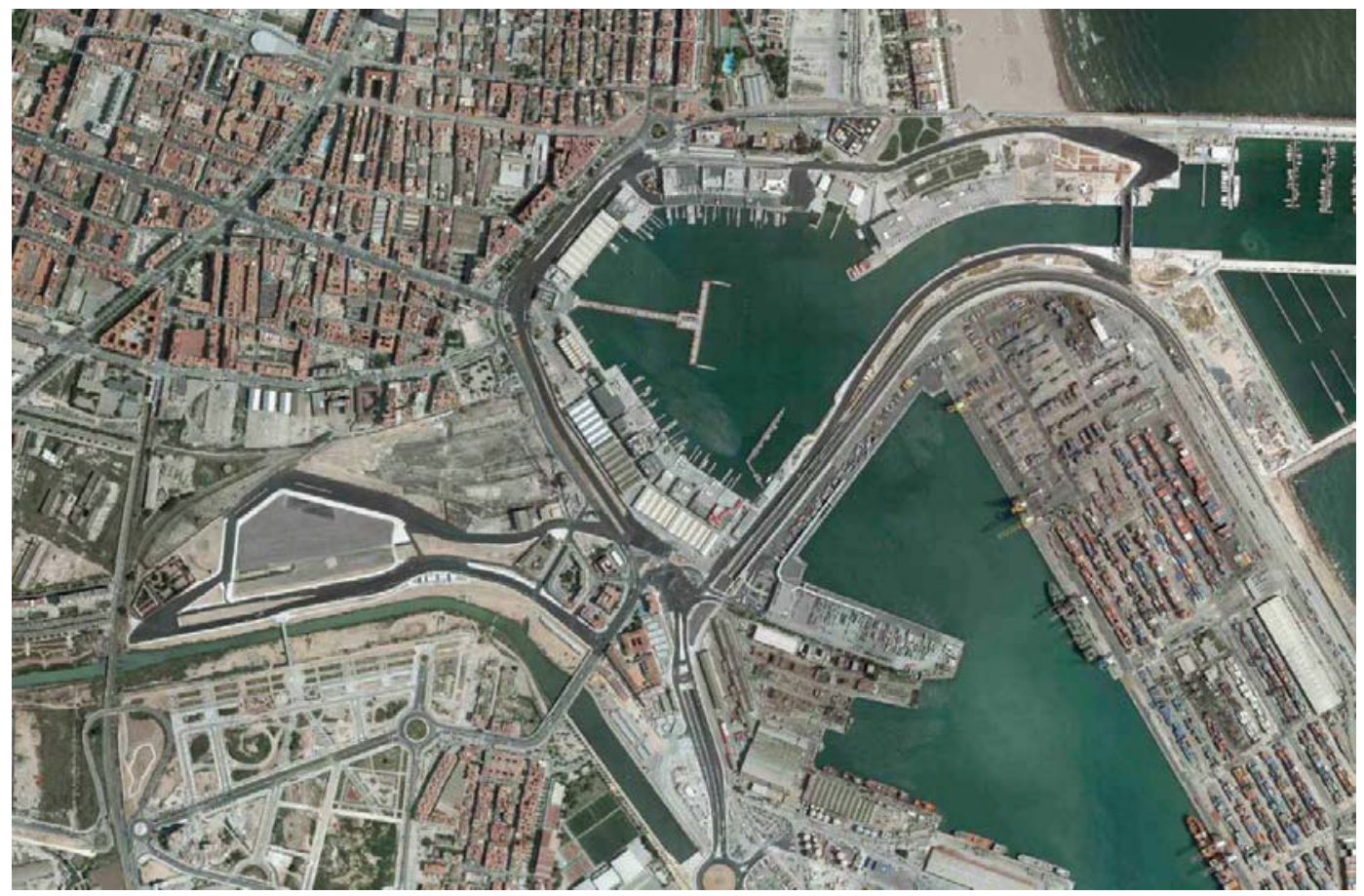

Figure 8: The Valencia Street Circuit unveiled in 2008 in the old docks and a former industrial site. It isolates the poor southern suburb of Nazaret from the rest of the city. The land around the circuit is currently being redeveloped to include luxury condos and hotels, according to a plan, by star architect Jean Nouvel. Source: Valencia Cartography Institute.

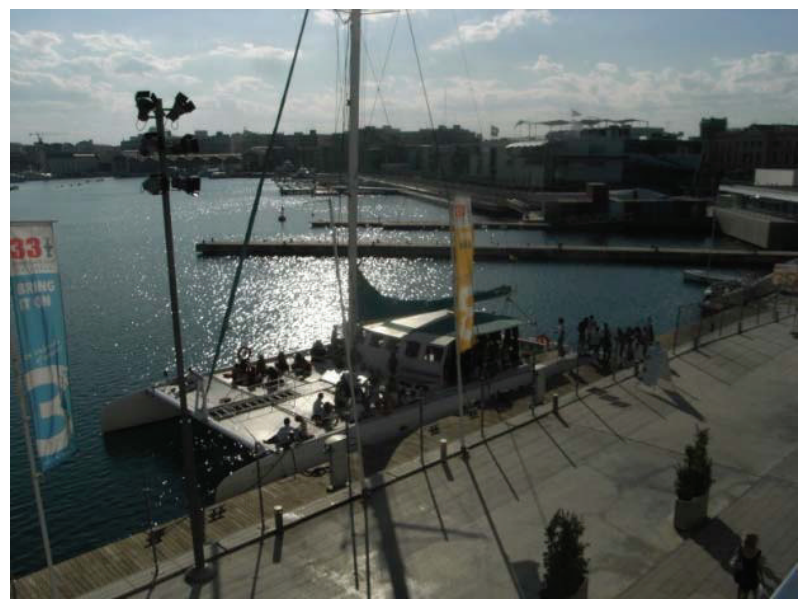

FIGURE 9: A VIP party in a catamaran in the former industrial port of Valencia, now a chic area with pubs, restaurants, and abandoned pavilions of the America's Cup.

industrial area into a sports infrastructure was adopted and approved within only one year.

Due to the lack of time (the final agreement was signed in May 2007 and the first Grand Prix had to take place in Fall 2008), the new street circuit was constructed without the obligatory environmental impact assessment. Although a denunciation of this default was officially submitted to the European Union, the project was completed and the first race took place on August 23 2008. A new polemic then

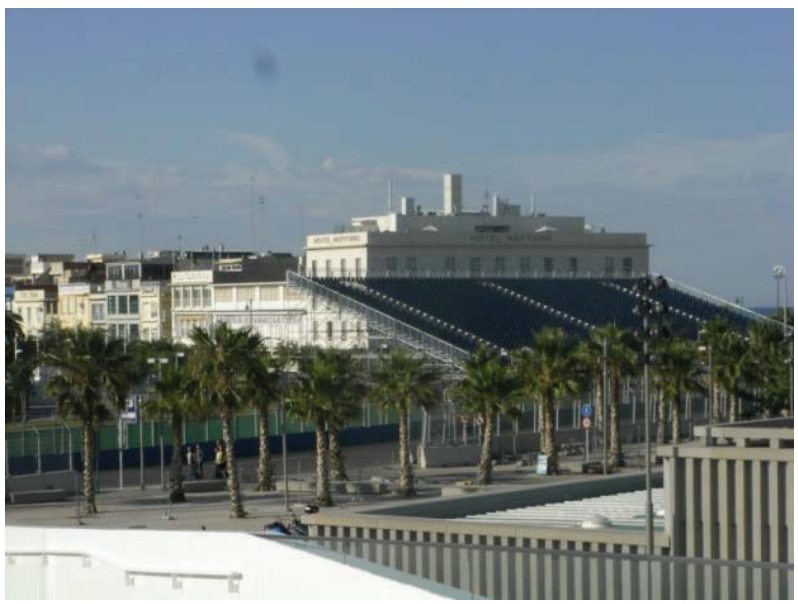

Figure 10: The F1 street circuit, only a few meters from the neighborhood of Malvarrosa.

arose a few days prior to the ceremony of the first great Formula 1 prize, when the town hall ordered to install a series of canvases in the southern limit of the circuit to conceal the abandoned industries and poorly maintained housing of the Nazaret neighborhood [8]. The town council had thus decided to cover up the poverty and degradation of some neighborhoods instead of investing in urban infrastructures and facilities that would improve the quality of life for the citizens of the area. 


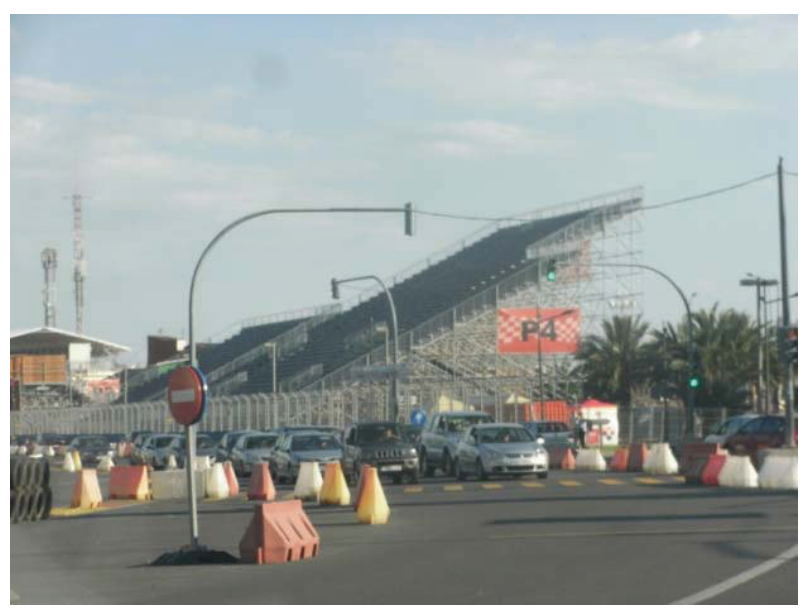

FIgURE 11: The adaptation of the city to a street circuit has created many traffic and access problems in the Nazaret suburb. Photographs: Luis Del Romero Renau (2009).

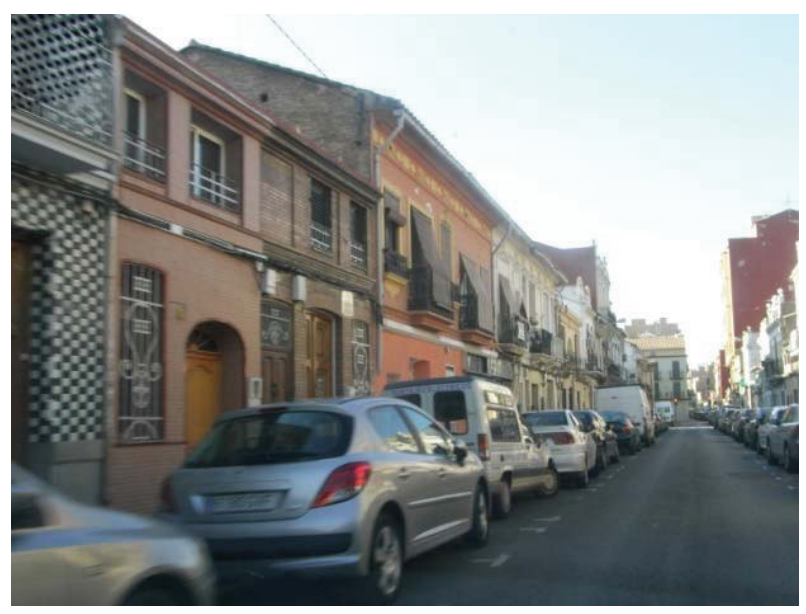

FIGURE 12: The El Cabanyal suburb with its traditional architecture, an area soon to be integrated into the "city of mega-events."

What is the heritage of the Valencia Street Circuit? A huge infrastructure that is used only once annually and that remains completely closed and abandoned for the rest of the time. The construction of the circuit involved major modifications to the urban structure (Figures 11 and 12) and destroyed various green areas that had been designed for the America's Cup and that were in planning as part of Jean Nouvel's project for the Valencia seashore. Thus, despite repeated affirmations by local authorities that the infrastructures built for the America's Cup and Formula 1 would have future uses, the circuit is a desert of concrete and fences for most of the year in addition to isolating the port and the city from the Turia River and from the southern neighborhood of Nazaret. The same applies to the former old port after the two America's Cup editions, which left behind them abandoned pavilions of the different teams and an expensive pavilion (The Chipperfield Veles e Vents pavilion), which has no utility whatsoever today (Figures 13 and 14).

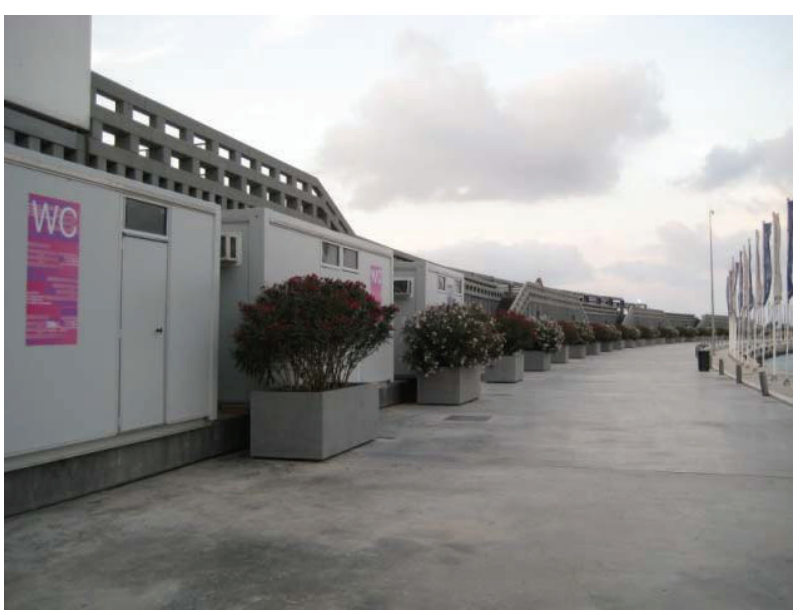

FIGURE 13: Current view of the old port: a completely empty pier with restrooms for the clients of the luxury restaurants installed there. Photographs: Luis Del Romero (2008).

Nevertheless, the areas surrounding the port and the street circuit are not completely deserted. New luxury condos, hotels, shopping centers, and marinas for megayachts are being built. The gentrification wave has definitely engulfed the area, clearing all signs of its industrial heritage and implanting a pseudomodernity consisting of lofts, boutiques, and luxury discos. A formerly well-known industrial site located next to the port is today one of the trendiest and most expensive discos in the city while the popular La Malvarrosa beach is now home to the Las Arenas hotel spa and convention center, one of the most expensive hotels in the region. And, as was shown in the case of the La Malvarrosa suburb, average housing prices per square meter have significantly increased.

\section{Conclusion}

According to the United Nations Commission on Human Settlements, "beautification" projects conducted immediately prior to international events are one of the most common justifications for slum clearance programs. The case of Valencia shows how two different sports mega-events served not only to create a new "image" of the city, but, more importantly, to start an urban transformation of the port area that would have been impossible under normal circumstances. The pressure of deadlines, the importance of the "image" that a city must project to other metropolises, and economic spin-offs were the reasons given by local authorities to transform-within less than four yearsa former industrial port surrounded by fishermen and working-class suburbs into a modern district for the sports mega-event.

The urban renovation and renewal process was wholly promoted by the public administration, which approved and provided all the necessary investments for the street circuit, the port reform, and even the fees-over 60 million eurospaid to Formula One Administration for being allowed to host the championship in the city [45]. Nevertheless, 


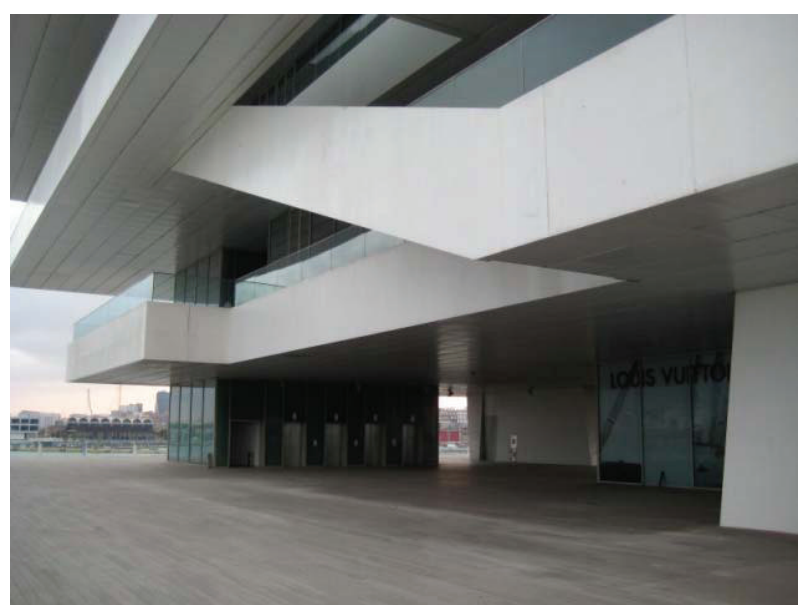

Figure 14: The main building of the America's Cup, which is today completely abandoned. The rooms are used to stock furniture used during the sailing competitions.

even after the holding of sports mega-events, most of the business goes to private real estate investors, hotels, and promoters. The role played by the local administration throughout the urban renewal process was simply that of a catalyst for the gentrification of Valencia's waterfront. The area had already briefly attracted the bourgeoisie at the end of the 19th century, but had remained a workingclass district by and large. Now, with the discovery that the working-class neighborhoods now providing affordable housing for senior citizens, workers, and immigrants could have a more profitable use, the area is once again in the hands of the wealthier classes. The gentrification began with the construction of marinas, luxury hotels, restaurants, condos, and apartments, constituting the perfect example of what Harvey [46] refers to as the "accumulation of capital by dispossession." In the case of Valencia, the lowincome and working class population was dispossessed of its dwellings and public spaces by the bourgeoisie, who returned to Poblats Marítim as the area had again risen in value. In Valencia, mega-events undoubtedly contributed to the production of space within the dynamics of capital reproduction.

However, the current struggle goes far beyond the classic class struggle, as it also comprises the destruction of important historic heritage. Most suburbs threatened by the kind of urban renewal plans accompanying the staging of the sports mega-events are historic suburbs that have a wide range of traditional architecture. In the case of Valencia, the gentrification process, initiated by the local administration, will invariably transform the historic character of the affected neighborhoods into "nonplaces," to use Augé's term [47], that is, into impersonal districts for wealthy people and a standardized waterfront in an anonymous area. In this research on urban conflicts in Valencia, one of the most important findings is the large number of newspaper articles related to conflicts evolving around the sports mega-events. The extensive press coverage of these urban conflicts shows that people do not want to see their milieu of life disappearing to become a theme park dedicated to Formula One supporters and tourists. Therefore, different urban-based organizations, citizens, and coalitions of actors demonstrated, got involved in conflict activity, and filed complaints - unfortunately without success.

Mega-event promoters as the Olympic Committee or the International Bureau of Exhibitions should pay more attention to the real impacts that international mega-events are having on the host cities, especially before and after the holding of those events. Otherwise, the current trend of multiplication of urban conflicts will grow stronger. For example, in Denver, Colorado, a majority of the city's citizens rejected the holding of sports mega-events, despite all the prestige, glamour, and positive image that such events promised to bring to the city.

\section{References}

[1] J. R. B. Ritchie, "Assessing the impact of hallmark events: conceptual and research issues," Journal of Travel Research, vol. 23, no. 1, pp. 2-11, 1984.

[2] M. Roche, "Mega-events and micro-modernization: on the sociology of the new urban tourism," British Journal of Sociology, vol. 43, no. 4, pp. 563-600, 1992.

[3] M. Roche, Mega-events and Modernity: Olympics and Expos in the Growth of Global Culture, Routledge, London, UK, 2000.

[4] G. Andranovich, M. J. Burbank, and C. H. Heying, "Olympic cities: lessons learned from mega-event politics," Journal of Urban Affairs, vol. 23, no. 2, pp. 113-131, 2001.

[5] H. H. Miller, "Mega-events, urban boosterism and growth strategies: an analysis of the objectives and legitimations of the Cape Town 2004 Olympic bid," International Journal of Urban and Regional Research, vol. 24, no. 2, pp. 439-458, 2000.

[6] COHRE, Fair Play on Housing Rights. Mega-Events, Olympic Games and Housing Rights, Centre on Housing Rights and Evictions, Geneva, Switzerland, 2007.

[7] K. Fox, "Theorizing urban spectacles: festivals, tourism and the transformation of urban space," CITY, vol. 9, no. 2, pp. 225-246, 2005.

[8] LEVANTE, "Natzaret exige soluciones y no lonas para camuflar las deficiencias," in El Levante, Valencia section, Spain, April 2008, http://www.levante-emv.com/secciones/noticia.jsp?pRef=2008041600_16_433591__Valencia-Natzaret-exige-soluciones-lonas-para-camuflar-deficiencias.

[9] S. Antón, "El desarrollo de parques temáticos en un contexto de globalización," Boletín de la Asociación de Geógrafos Españoles, vol. 28, pp. 85-102, 1999.

[10] M. Dachevsky, Urban Zapping. Ciudades, productos y marcas, Edicions de la UPC, Barcelona, Spain, 2001.

[11] G. Debord, La Société du spectacle, éditions Gallimard, Paris, France, 1992.

[12] H. Lefebvre, Critique de la Vie Quotidienne, L'Arche, Paris, France, 1958.

[13] D. Harvey, "Voodoo cities," in New Statesman and Society, vol. 1, pp. 33-35, Edinburgh University, Edinburgh, UK, 1988.

[14] O. Nel Lo, Aquí no ! Conflictes Territorials a Catalunya, Plaza Edición, Empúries, Spain, 2003.

[15] F. Ascher, Los Nuevos Principios de Urbanism, Alianza Ensayo, Madrid, Spain, 2004.

[16] M. Castells, The Power of Identity: The Information AgeEconomy, Society and Culture II, Blackwell, Cambridge, Mass, USA, 1997. 
[17] J. Borja, La Ciudad Conquistada, Alianza Ensayo, Madrid, Spain, 2003.

[18] J. Sanko, "Colorado only state ever to turn down Olympics," in Denver Rocky Mountains News, 1999, http://denver.rockymountainnews.com/millennium/1012stone.shtml.

[19] K. Heim, "Anti-Olympics protesters converge on Vancouve," in The Seattle Times, 2010, http://seattletimes.nwsource.com/ html/localnews/2011027936_olyprotests10.html.

[20] G. Cox, "Showing off or showing up the city? The social impacts of major events," in Proceedings of the 16th Annual Meeting of the International Association for Impact Assessment, Lisbon, Portugal, June 1996.

[21] C. Trudelle, P. Villeneuve, M. Thériault, and M. Pelletier, "Becoming visible: women and conflicts in the Quebec metropolitan areas, 1965-2000," Urban Studies, vol. 43, no. 12, pp. 2183-2203, 2006.

[22] P. Villeneuve, M. Pelletier, and M. Thériault, "The social dynamics of urban neighbourhoods: methodological essayLa dynamique sociale des quartiers urbains: essai méthodologique," Espace-Populations-Societes, vol. 1, pp. 135-148, 2009.

[23] P. Villeneuve, C. Trudelle, M. Pelletier, and M. Thériault, "Acteurs urbains en conflit, Québec, 1965-2000 : essai d'analyse statistique," Géocarrefour, vol. 81, no. 2, pp. 135-141, 2006.

[24] C. Trudelle, Visibilité de la participation des femmes aux conflits urbains à Québec entre 1965 et 2000, Thèse de doctorat, École supérieure d'aménagement du territoire et de développement régional, Université Laval, Québec, Canada, 2005.

[25] S. Olzak, "Analysis of events in the study of collective action," Annual Review of Sociology, vol. 15, pp. 119-141, 1989.

[26] D. Rucht, R. Koopmans, and F. Neidhardt, "Introduction: protest as a subject of empirical research," in Acts of Dissent: New Developments in the Study of Protest, D. Rucht, R. Koopmans, and F. Neidhardt, Eds., pp. 7-30, Rowman \& Littelfield Publishers, Lanham, Md, USA, 1999.

[27] J. Earl, A. Martin, J. D. McCarthy, and S. A. Soule, "The use of newspaper data in the study of collective action," Annual Review of Sociology, vol. 30, pp. 65-80, 2004.

[28] V. Blasco Ibáñez, Flor de Mayo, Cátedra, Madrid, Spain, 1895.

[29] F. Beltrán, "El Cabanyal: Valencia’s last window to the Mediterranean," Babelmed, 2010, http://www.babelmed.net/Countries/Mediterranean/el_cabanyal.php? $\mathrm{c}=5689 \& \mathrm{~m}=98 \mathrm{l}=\mathrm{en}$.

[30] LEVANTE, "El puerto de valencia renuncia a participar en la operación urbana del balcón al mar," in El Levante, Valencia section, Valencia, Spain, October 1997.

[31] C. Trudelle, "Beyond social movements: a relational typology of urban conflicts Au-delà des mouvements sociaux: une typologie relationnelle des conflits urbains," Les Cahiers de Geographie du Quebec, vol. 47, no. 131, pp. 223-242, 2003.

[32] M. Pelletier, F. Joerin, Y. Kestens, and P. Y. Villeneuve, "Conflict Activity in the Neighborhoods of Quebec City (Canada), 1989-2000," Applied Spatial Analysis and Policy, pp. 1-27, 2010.

[33] D. G. Janelle and H. A. Millward, "Locational conflicts pattern and urban ecological structure," Tijdschrift Voor Economische en Sociale Geografie, vol. 67, no. 2, pp. 102-103, 1976.

[34] D. G. Janelle, "Structural dimensions in the geography of location conflicts," Canadian Geographer, vol. 21, no. 4, pp. 311-328, 1977.

[35] D. Ley and J. Mercer, "Locational conflict and the politics of consumption," Economic Geography, vol. 56, no. 2, pp. 89-109, 1980.
[36] L. Del Romero and C. Trudelle, Le conte de deux cités*: analyse comparative des conflits urbains de Montréal et Valence. Le Géographe canadien/The Canadian Geographer, Accepted for publication.

[37] CEyD, Valencia en los primeros años del siglo XXI. Análisis de situación para la Estrategia 2004-2015, Centro de Estrategias y Desarrollo Documento, para el debate, Valencia, Spain, 2004, http://www.ceyd.org/biblioteca/publicaciones/documentos_ trabajo/default.php.

[38] H. García, "El consorcio anuncia sobrecostes de 33,6 millones de euros en las obras de la Copa," in Levante, Valencia, Spain, January 2007.

[39] Ayuntamiento de Valencia, Anuario estadístico 2009, Valencia, Spain, 2009, http://www.valencia.es/ayuntamiento/estadistica .nsf/vDocumentosTituloAux/Novedades?opendocument\&lang=2\&nivel $=1$.

[40] L. Lees, T. Slater, and E. Wyly, Gentrification, Routledge, New York, NY, USA, 2008.

[41] P. Varea, "Los vecinos denuncian que la mayoría de las obras en barrios no están hechas," in Levante, Valencia, Spain, June 2006.

[42] N. Smith, "Nueva ciudad, nueva frontera: el Lower East Side como oeste, salvaje oeste," in Variaciones Sobre un Parque Temático. La Nueva Ciudad Americana y el Fin del Espacio Público, M. Sorkin, Ed., Gustavo Gili, Barcelona, Spain, 2004.

[43] D. Barcala, "La Generalitat invertirá más de 60 millones en el circuito de fórmula uno," El País Comunidad Valenciana, Valencia, Spain, June 2007, http://www.elpais.com/articulo /Comunidad/Valenciana/Generalitat/invertira/millones /circuito/formula/elpepiespval/20070719elpval_3/Tes.

[44] LEVANTE, "Fórmula Verda considera incompatible el circuito y el delta verde de Nouvel," in El Levante, Valencia section, Valencia, Spain, November 2007.

[45] Ecologistes en Acció, "La fórmula 1 un sac sense fons que haurem de pagar entre tots," Valencia, Spain, 2009, http://www.ecologistasenaccion.org/spip.php?article15267.

[46] D. Harvey, Spaces of Global Capitalism. Towards a Theory of Uneven Geographical Development, Verso, London, UK, 2006.

[47] M. Augé, Los No-Lugares. Espacios del Anonimato. Una Antropología de la Sobremodernidad, Gedisa, Barcelona, Spain, 1993. 


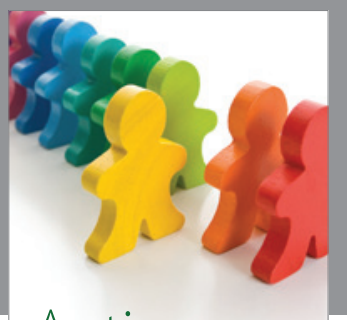

Autism

Research and Treatment
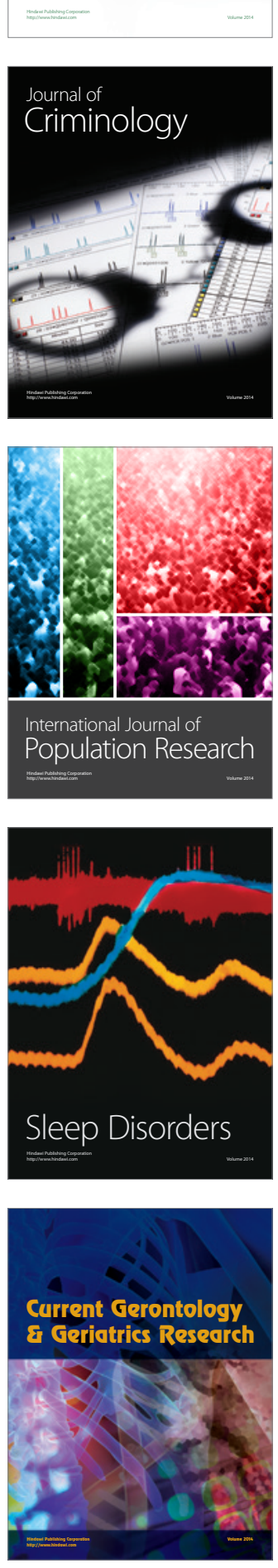
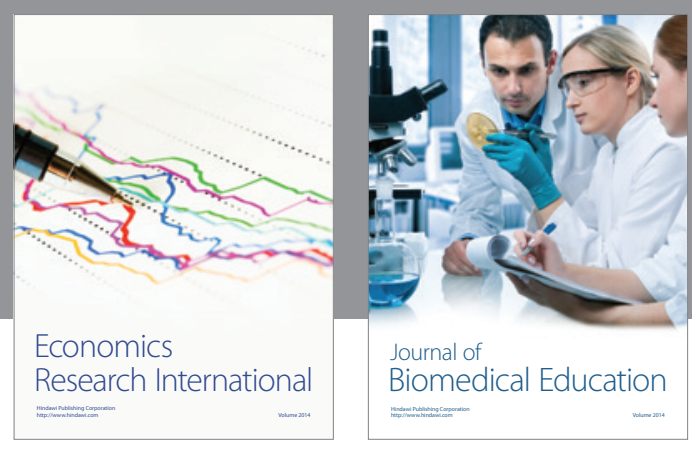

Journal of

Biomedical Education

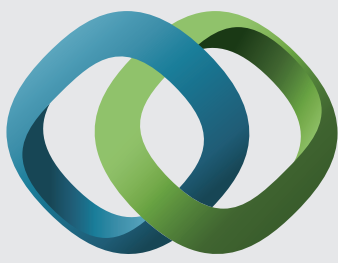

\section{Hindawi}

Submit your manuscripts at

http://www.hindawi.com
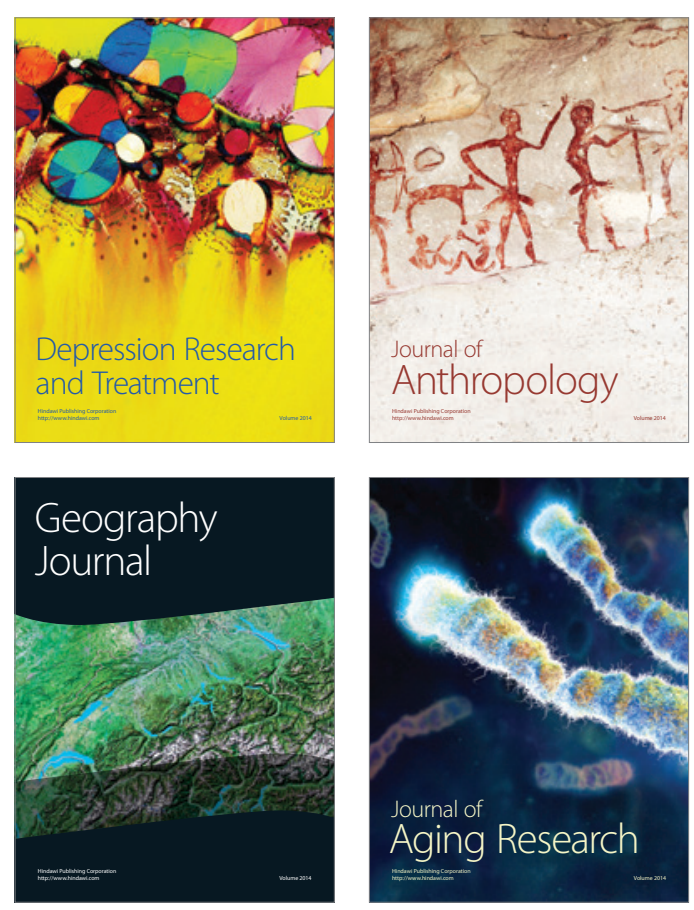

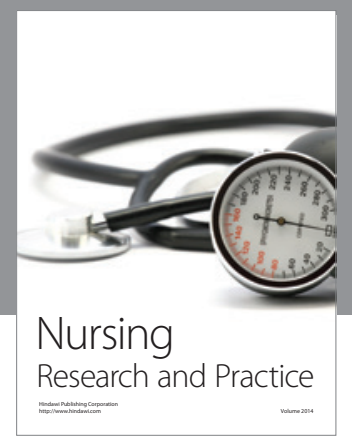

Nursing

Research and Practice

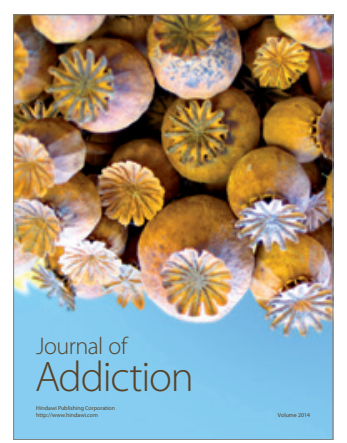

Child Development

Research

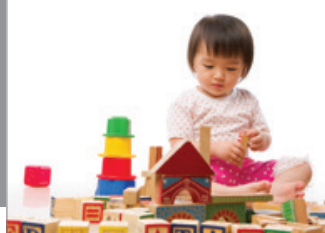

迥
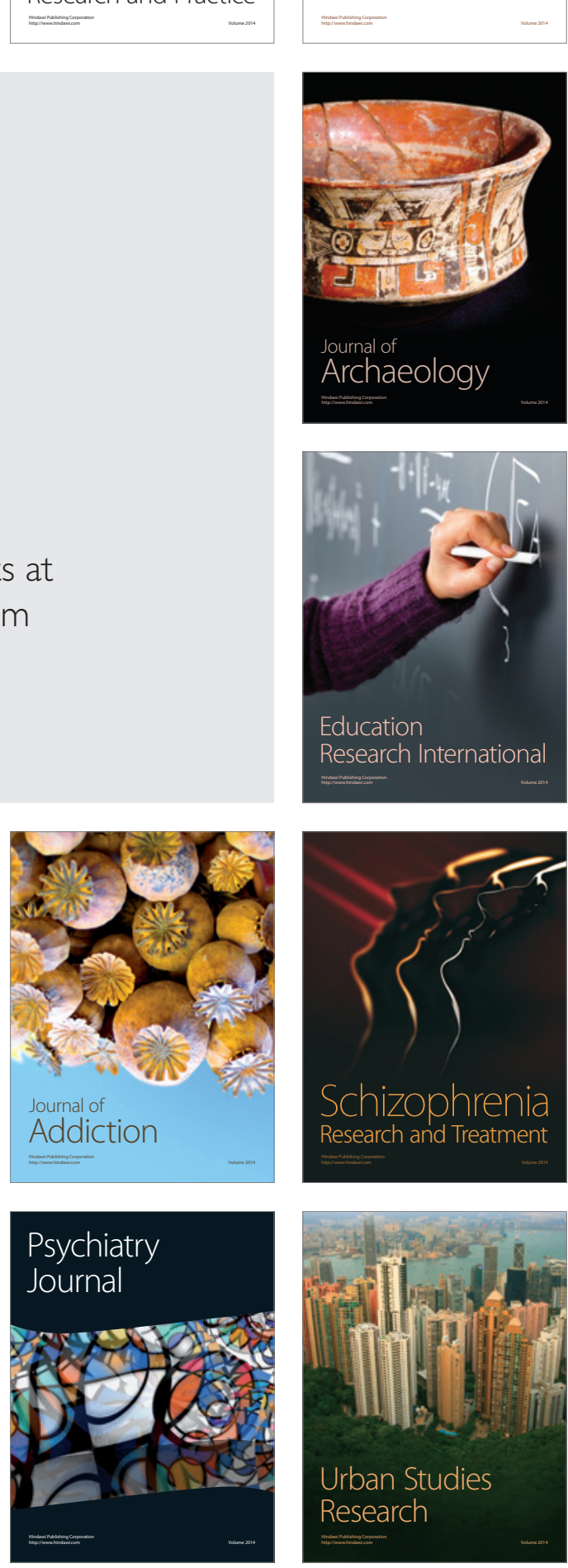